http://dx.doi.org/10.7833/116-1-1345

\title{
FEMINIST CRITIQUE OF THE EDUCATION MODEL OF MABEL SHAW GIRLS' BOARDING MISSION SCHOOL IN ZAMBIA 1915-1940 AND ITS EFFECT ON THE EDUCATION OF GIRLS
}

\author{
Lilian Cheelo Siwila \\ University of KwaZulu Natal
}

\begin{abstract}
Missionaries that came to southern Africa had much to offer to the local people of this part of the continent. One of the tasks of the missionaries in the mission field was to introduce mission schools. In central Africa the London Mission Society emerged as one of the main mission bodies that introduced mission schools to young African boys and girls. This study provides a critical analysis of the education model that was introduced at Mable Shaw Girls' Boarding School in Mbereshi, Zambia. The study used a textual analysis approach and religio-cultural feminist lens to argue that missionaries such as Mable Shaw misrepresented the African model of girl-child education in their attempt to incorporate African education systems into the western form of education. The study found that Shaw's approach to women emancipation as a feminist was ambivalent in that while she fought for white women's rights in her school, she failed to promote the empowerment of the girls. Instead, she encouraged patriarchal ideologies that perpetuated the oppression of girls through the promotion of child marriage. This study concludes that in as much as feminism aims at fighting for the liberation of women from all forms of oppression, there is need to take into cognisance the power dynamics at play between western feminism and third world feminism.
\end{abstract}

Key Words: Girls' Education; Feminism; Mission Boarding School; Colonialism; Mable Shaw; African Culture

\section{Introduction}

Mission boarding schools are one of the models of education system that was introduced by the missionaries in Zambia during the colonial era. Most of these boarding schools adopted a model with a preference for what was called single sex education. In this system boys and girls were educated separately, unlike co-education where the genders were combined in one school. In the few mission schools that adopted the latter, the system introduced stringent measures that prevented boys and girls from socialising except under strict supervision by the boarding matron or master. At most, these boarding schools attracted positive responses from local communities. Leaners who went through mission education were held in high esteem by their communities. Even in the current state, Zambian mission boarding schools are still seen as providing the best education system. Children who go through these boarding schools are expected to be of good moral standing and attain a higher academic performance due to the standard of education being offered in these schools. The schools are also praised for the kind of discipline instilled in these learners. Back into their communities, children from mission boarding schools were valued for their exceptional spiritual conduct. 
This article intends to analyse the education model of one of the mission boarding schools that was built under the London Mission Society in Zambia. Mabel Shaw Girls' Boarding School in Mbereshi Zambia is one of the oldest and most famous mission boarding schools that set up a unique education model for girls. While the community upheld the model set in this school as good for their children the model itself also stands to be critiqued especially in the area of systems that were used to teach these girls. What was common in mission boarding schools is that despite their positive efforts to educate the young people, their models of education had some negative aspects that had an effect on the African values.

In my analysis of the education model offered in this school, I employ a feminist cultural lens to interrogate how African cultural values were incorporated in the syllabus and how the combination of western education and African education informed the preparation of a girl for marriage. The article will also analyse how Mable Shaw's model of education for girls contradicted with the ethos she claimed to embrace. This reviews how feminism worked alongside colonialism in perpetuating the oppression of African women in the mission field.

\section{Mabel Shaw and the Introduction of the GBS in Northern Rhodesia (Zambia)}

Morrow (1986) is among the few scholars who have done an extensive study on Mable Shaw and the girls' boarding school in Zambia. In his discussion of the statement "No girl leaves school without marriage" he illustrates how Mable Shaw prioritised marriage of these girls over their formal education and pursuit of any other career paths that they had hoped to pursue. Hughes provides the autobiography of Mabel Shaw stating that she was born in Wolverhampton to a lower-middle-class non-Christian family. Mable was the eldest of the five children. When she was five years old she was sent to live with her grandmother in Berkshire, where she stayed until her grandmother's death five years later. She credited her Baptist 'Granny' with teaching her "how near God was in everyday things in this world". It is this theology that underlay Shaw's work in Africa (2013:105-108). The author further provides a detailed account of Shaw's education that:

Shaw went to a boarding school on the Isle of Wight and did elementary education together with her Christian education... During this period she also found time during her vacations to actively support the work of London Mission Society. She later took up studies on missions at St Colm's College, Edinburgh and later became a missionary to Central Africa under the LMS. Mabel Shaw was the first single woman to be appointed for mission work in central Africa. She accepted the offer willingly "praying that she would follow in the footsteps of David Livingstone" (2013:107).

Whether she was motivated by the fact that she herself went to boarding school or not, her first task in the mission field was to set up an all-girls boarding school. During this colonial era, the idea of boarding schools in Africa was a prominent model of providing education in the mission field. Mabel Shaw was the first most renowned missionary woman to open a girls' boarding school in Northern Rhodesia. She arrived in the country in 1912, sent by the London Mission Society (LMS). Upon arrival in the then Northern Rhodesia, she embarked on the project of girls' education which was her greatest passion as a missionary. This led to the founding of the LMS Girls' Boarding School in Mbereshi named after her, as Mabel Shaw Girls' Boarding School. Shaw headed this school from 1915-1940 as the principal 
and instructor. Mabel Shaw Girls' Boarding School was the first mission boarding school for girls in Northern Rhodesia. ${ }^{1}$ Hughes states that:

This school not only educated numerous girls between these years but also served as a model for other mission schools. In addition to her work in Africa during an era when most African women either were obscure to the British public or were considered to be conservators of the primitive, Shaw instead presented them as concerned and active members of a changing society. Finally, Shaw should be remembered as an authority billed as 'an interpreter of Africa'. Her communication skills and her insights into missions work earned her recognition as an expert in a male-dominated field (2013:10).

Although the idea of introducing a girls' boarding school was seen as a solution to girls' education, this move did not go without challenges. Most of the missionaries from the London Mission Society (LMS) and the colonial government reacted to this decision. The main argument was around the idea of introducing an all-girls boarding school when other mission stations and government schools within the country were promoting co-education for both boys and girls. This however does not mean that either these missionaries or the colonial government had embraced gender equity in the education system of the country to the contrary. From a gender perspective, the colonial era was one the most patriarchal periods due to the merging of two patriarchal cultures - the host culture and the foreign culture which were both oppressive to women. Hence to say that the introduction of an allgirls school by Mable Shaw was to promote the emancipation of women remains debatable since the education of women could not be compared to the kind of education offered to the boys. The few girls that went through formal education could not compete with boys when it came to employment opportunities since most of the jobs were still predominantly maleoriented.

The other resistance was against the fact that Shaw's intention to introduce an all-girls' boarding school fell within culturally-determined patriarchal structures that were not accommodating the western form of girls' education. One would argue that this could have been one of the influencing factors for Shaw's call for girls' education. On the other hand, a feminist reading of the preference of an all-girls' boarding school brings out the concept of the Victorian model of housewife ideology, i.e. educating the African girl to become a civilised home maker and good housewife. Looking back at her twenty-five years of service in what was called Northern Rhodesia, Shaw remembered what she called her first "...four little wild untamed girls, unclean in person, in habits, in thought and in speech. Like the vegetation of the compound, girls were 'redeemed from un-regenerate life and year by year disciplined into gentleness"' (1986:624). Shaw died in 1973 and her ashes were brought back to the Mable Shaw school where they were buried on the grounds of the chapel at Mbereshi. The school is now under the governance of the United Church of Zambia.

\section{Mable Shaw's Feminist Approach to Leadership in Mission}

Most male missionaries who worked closely with her at the LMS office called Mable Shaw a feminist, based on her desire to have an all-girls boarding school. Those who called her a feminist also cited the manner in which recruitment of staff for her school was carried out: Shaw had decdided to recruit only female staff in her school, for which she came under fire with the authorities from LMS. This is despite the fact that the call for female missionaries

Most of the work in this article is derived from the scholarship of Sean Morrow, a scholar who has written much on the work and history of Mabel Shaw. A detailed account on this information can be obtained from Sean Marrrow, “The Missionary in the Black Girl in Shaw”, Vol. 6. 1986:5-12. 
to be sent to central Africa from the LMS head office had been under discussion over a long period. Regarding the scarcity of female missionaries, Morrow (1986) states that in 1910 the motion was passed to permit female missionaries more opportunities for mission work. ${ }^{2}$ Most of these female missionaries found themselves working at Shaw's GBS through her persistent request that the LMS office sends only women to her school. In her defence of the reason for recruiting only single women missionaries to teach at the school, Shaw argued that her girls would not be taught by any male missionaries. The reason was that she did not see any need for male missionaries to be accorded another chance to work in the school since they had always been privileged by the mission field. This was despite many attempts by the LMS to persuade her to see the need to develop a gender-balanced group of staff members who were qualified for particular positions.

Apart from refusing to recruit male missionaries in the school, Shaw also refused married women missionaries in her school. In her justification of the reasons to that effect she is quoted by Morrow saying "unmarried female missionaries had a more vital role in Africa than married women". This is because these unmarried women encourage an ideal of African women who lived for God, not just for men: "It is the celibate woman missionary in Africa today who is creating a revolution amongst married women in Africa - giving them a new sense of their value." For Morrow, Shaw was trying to illustrate that women are liberated by the possibility of remaining unmarried after puberty, and are no longer the virtual slaves of men (Morrow, 1986:611). Another LMS missionary, James Ross, quoted by Morrow, seeing the almost inevitable position of a missionary's wife, wrote in 1906: "May God save us men from requiring another Apostle to simply wait upon us" (Marrow, 1986:611). With all these sentiments Shaw defended the presence of single female missionaries as a good cause for the girls' education. Despite all the resistance from the LMS office, Shaw got away with the pressure and managed to appoint single women missionaries at the school.

\section{Ambivalences in Shaw's Feminist Agenda}

Looking at the ways in which Shaw pushed her feminist agenda to the LMS and how she presented the girls' education in the mission field, we see some ambivalence in the way in which she presented feminism. While standing for the rights of women, her statements such as the one by Morrow above, where Shaw is quoted describing the native girls as "four ... little untamed girls... unclean in person, thought and spirit ... redeemed from un-generate life year by year", reflect a seriously undermining attitude to the Africans. Here the ambivalence manifests itself through the class positioning of the African person by the person - an approach that was very common in the mission field reflecting the racial class system. Responding to issues of class Ruether (1989:222) argues that all women are marginalised and subjected relative to males, but as members of class and race hierarchies, women occupy class levels. These class levels sometimes draw women to marginalise women of the lower classes and be in partnership with men of their own class (Ruether 1989:222), as was the case during the colonial era.

Sean Morrow, "No Girl leaves School unmarried: Mabel Shaw and the Education of Girls at Mbereshi Northern Rhodesia 1915-1940”, The International Journal of African Historical Studies, Vol. 19 No 4 (1986) 601-635, Boston University African Studies Centre. This is another work that has been used to explore the history of the GBS in Mbereshi Zambia. 
At the same time Shaw's approach to supporting single women missionaries again reflects another angel of understanding feminism. Ruether (1989) says that for radical feminism the core issue is the emancipation of women:

"Unmarried women encourage an ideal of African women who lived for God, not just for men: It is the celibate woman missionary in Africa today who is creating a revolution amongst married women in Africa - giving [them] a new sense of their value."3

A critical analysis of these quotations review first a missionary woman whose vision was to create a holistic radical change among African girls, and a feminist standing up for the rights of single women. Her desire for celibacy as a tool to empower the African woman against all forms of patriarchal oppression related to marriage stood as good cause, although the outcome of her teaching model was different.

In an article, The Missionary in a Black Girl (1986), Morrow, states that Mabel Shaw was a feminist, though an ambivalent one. With what she called "kind of sex pride" she rejected all efforts by male missionaries to control her work (Morrow, 1986:7) in her fight against all forms of sexism. Morrow, describing Shaw's feminism reports, that:

The feminism of the GBS was linked with these unmarried women with a glorification of motherhood (motherhood more fundamentally, perhaps, than matrimony) which, while it isolated and elevated the female role, regarded that role as expressing itself so particularly in the development of functions specific to femininity that broader questions of female equality within the socioeconomic structure were marginalised. The sexes were to be equal but separate. It is on these ambiguous foundations that the feminism of Shaw and her staff was built (1986:612).

The points raised by Morrow bring out the fact that feminism itself is diverse, that it means different things to different people (Clifford 2001). In relation to married life, Mabel Shaw described herself as someone who had moved from 'novitiate' to the conscious rejection of the possibility of marriage and children (Morrow 1986:611). Shaw's approach to feminism can be summarised in the words of Ruether when she states that for radical feminism the core issue is women's control over their own persons, their bodies as vehicles of autonomous sexual experience and their own reproduction (1993:228). Shaw's approach to her own marriage, life and child-bearing contradicted the education model that she put across in her school where she placed much emphasis on the need for girls who graduated from her school to get married, with a slogan, "No child leaves school without marriage.", Therefore, it becomes evident that Shaw's feminism was ambivalent in many ways hence deserving critical gender analysis.

\section{A Feminist Critique of the Education System in the Mission School Mable Shaw GBS}

During the colonial era, mission education became the main form of education provided for Africans, since it provided a vehicle for reaching the missionaries' target of conversion. Most of the missionaries emphasised the need for Africans to be literate in order for them to acquire basic reading and writing skills in the language of their colonial master. This is because language is a powerful tool for constructing reality. At the same time, in whichever way it was presented, a number of scholars would argue that mission education aimed to fill

Morrow 1986 quoting Shaw when she emphasised the need for only celibate mission women to join the school.

4 This was a strong emphasis for the ethos of the school, itserved as the motto which guided the education principles of the school. For more information, see Morrow, "No Girl Leaves School Unmarried" 1986. 
the educational gap left by demise of ethnically-based circumcision and initiation schools (Gaitkskell 1979, 1982, 1983, Hasen 1992, Morrow 1986). In the Mable Shaw GBS, girls were still allowed to undergo initiation ceremonies under the instruction of female instructors appointed by Shaw. These bana chimbusa (women instructors) instructed the girls during initiations using what was called a missional framework, whilst maintaining African cultural values. Morrow (1986) says that this model of education was reflected in the curriculum of the school.

In relation to the curriculum and educational standing, Morrow (1986) further indicates that as the founder of the GBS in Mbereshi, Shaw herself had no academic training in education but rather depended on the limited teaching background she acquired while serving as a trainee missionary in her home country. Her approach to education focused on the 3 Rs (Reading, Writing and Arithmetic) coupled with hygiene, mother craft and gardening. Since Shaw's main focus in the education of the girls was to prepare them for marriage, much of the emphasis in the syllabus fell on social skills other than the 3Rs. Commenting on the missional colonial education system Iris Burger states that:

Colonial ideologies of social control generally expressed through mission sponsored education aimed at casting the African woman into the mould of late Victorian wives and mothers, elite girls' boarding schools aspiring to shape generations of married Christian mothers assumed strong control over the pupils' puberty and marriage in an obsessive effort to keep their chances from the shape of premarital pregnancy (1999:40).

Shaw's approach to education also considered the context from which the learners were drawn. A positivist approach to this model of running the school will show that Shaw was culturally correct in that she was operating within the morally accepted norms of that particular local context. Some of the ways in which these norms were demonstrated was through marriage of these girls. Shaw taught that for a girl marriage was the highest value for her education. This is confirmed by Morrow who states that in making the assumption that all females would marry before leaving school, the GBS did not differ from the pupils' own society, except that the school girls married later than was the norm for the time and place (1986:622).

Second, the need to develop a Victorian housewife out of the native girls emerges as one of the core values of this boarding school education system (re-generating her year by year...). This was reflected in the syllabus which also aimed to teach the girls basic home economics skills which were meant to prepare girls to be good housewives. Despite the tremendous contribution missionaries made through evangelism and education, their perception of Western culture as superior to African culture was always manifested through the way in which they treated the natives in the mission field. For example, the idea to impose both Christianity and a Western way of life, worldview and ideologies by undermining local religion, tradition and culture was one way of showing the superiority of their culture. The Victorian family model and "the cult of true womanhood" provided an "ideal answer for a family model that was accepted during western industrialisation" (Gaitskell, 1983:244). When applied in the mission field, women and girls were taught to be good wives and mothers in a way to produce 'progressive wives' (Parpat, 1996) or 'home makers' (Gaitskel, 1983:223).

In illustrating how this model worked among African women, Fraser quotes a woman taking a course in domestic science, saying: "It would bring me in the way in which my husband would like ... those who are learning now will not think they are improving ... but when they go back they will find out what they know" (Fraser 1943:240). The response from this woman implied that acquiring domestic training was seen as a sign of conversion 
to Christianity and accepting Christian morality and ethics. Consequently, it was also this Western view of married women as the 'angel' in the domestic sphere that could have influenced Shaw to put marriage at the top of her agenda in the training of the girls at her school.

\section{Effects of Class Boundaries to Feminism and Women Emancipation}

As a European middle class, feminist missionary Shaw found herself trapped in Eurocentric ideologies that informed the way she perceived the girls in her school. She also struggled with class boundaries between herself as a missionary from a privileged position and the underprivileged native black girls whom she had to develop into modern African women. This kind of feminist approach was common during the colonial era. Feminist missionaries tried by all means to maintain class boundaries that continued to be seen as spaces of struggle and negotiation between the coloniser and the colonised. Women's heightened role in the colonies was due not only to Victorian views of women but also to change in the general sense of what civilising was all about (Morrow 1986:9). At the same time we cannot rule out the Victorian view which accorded white European women a privileged position over their sisters in the third world countries. Therefore, Shaw's attitude towards the girls whom she was educating also carried these imperialistic tendencies of "them and us".

\section{Victorian Model of Education to the Girl-child}

The Victorian model exposed the girls to a European form of education introduced by the missionaries and the colonial government. In relation to marriage and family life of the native Africans, Morrow states that:

...her aim was to prepare Christian wives and mothers in an all-female environment, and the school was organised with this end in view ... Mabel Shaw was unwilling to bow to pressures from any source, and her stubbornly Christian view of education led her to take stands that could conflict with colonial officialdom. Education for Mabel Shaw was primarily a moral rather than an academic process. In 1935, for instance, she noted that Standard IV girls were eagerly studying for their government certificate. "We are determined," she said, "to correct this, and bring their thoughts back to a worthier concept of education" (1986:8).

This kind of subjection of the girls through what was seen as a worthier and noble root of education can be critiqued through the lens of both the African and Victorian concepts of marriage and what it meant for a woman to be a housewife. African women theologians such as Phiri (2003) have demonstrated in many ways how marriage has been oppressive to women in most African societies. These authors further argue that marriage is a centre for patriarchy. Therefore, encouraging the girls to enter into marriage only perpetuated the patriarchal oppression of girls. Second the Victorian model of housewife simply domesticated the girls even further by removing them from the public sphere of production to the private sphere where they were to carry out the role of motherhood and take care of the male leader of the house.

\section{Education for Heavenly Glory}

In as much as moral education was good for a girl, suffice it to say that Shaw's idea of refusing these girls to enrol and write government examinations which awarded them with academic certificates was a further instance of oppression of the girls as it further denied 
them an opportunity to enter the secular world of employment. What was called Christian education could also be critiqued for its Christian essence and moral ethos. What was moral about forcing the girls into what was called Christian marriage soon after the end of the primary level of education? In all these deliberations Shaw defended her education system, arguing that it was about teaching children to be

...colonists of heaven... To make it concrete, every book we read, every exercise given and done, every story and game must be an exercise in the seeing of the Lord of all good life, in learning from Him how the kingdom of the world may be so cleansed and renewed and recreated that it becomes the one Eternal Kingdom of Our Lord. That is our faith, 'educational' faith, our definition of education. ${ }^{5}$

As indicated earlier, the missionary education model also acted as a form of conversion for the Africans. Shaw defines her model of education above also as 'educational faith.' Whatever these girls learnt, was also considered as a ticket for them to get to heaven. As Shaw indicates in her words, the aim of making them 'colonists of heaven,' meant that the syllabus was focused toward forming believers suitable for heavenly glory.

\section{Shaw the Matchmaker}

A critical view of Shaw's approach to girls' education shows that she perpetuated the patriarchal tendencies that oppressed women through marriage. Reuther (1988) argues that patriarchy means above all the subordination of women's bodies to male ownership and control. Shaw played a patriarchy role of mediating marriages of these girls in a maledominated society. This also challenges her feminist claims of calling for women's liberation when she demanded for women participation in mission. For playing the role of matchmaker and being the final voice in the marriage of these girls Shaw interfered with the traditional norms of the girls' societies by taking over the patriarchal roles of their parents in the decisions about the marriages of their children. In some cases, Shaw exercised power over what she considered unsuitable matches and became the decisive voice in the marriage arrangements. The first person the man or the family of the man intending to marry approached was generally Shaw, and only after her approval was the couple allowed to meet and talk to each other. The trysts happened in a small hut that was strategically situated for visibility in the school. Only after that meeting did the normal mpango contract proceed (1986:622). In all these deliberations, the girl was not empowered to voice her views. The intervention of Shaw in the marriage arrangements was a contradiction of the cultural expectations of an African community where the marriage contract is mostly between parents. At the same time, Shaw perpetuated the silencing of the girl by denying them the power to make decisions over their marriages. Morrow further contends that the role of the school in approving and even organising this vital link, not only between two individuals but between two family or kinship structures, is notable. In this role the GBS went well beyond the functions of a girls' school as normally conceived of in Britain and involved itself in an area of central importance to African life (1986:622) which was marriage.

5 The statement is quoted by Morrow who cites Shaw; see NAZ/NR 2/240, LMS, Mbereshi Girls' School and Jeanes 1938-54, Shaw to Tyndale-Biscoe, 8 April 1938, Mbereshi. 


\section{Girl-child Education for Man's Glory}

Lastly, another point that needs interrogation is who benefited from these marriages. Although some girls found pride in their marriages, the main beneficiaries in these marriages were the men who married these girls and Shaw who found fulfilment in her career objective. The decision to marry these girls was done under Shaw's strict instructions as the matchmaker. In man's world, one of the reasons for the introduction of the all-girls school at Mable Shaw girls' boarding school was the need for educated women who would serve as wives of the African male elite, especially those who were training to be pastors. The LMS where the school was located was responding to the pressure from the African male elite who demanded educated girls who could be fitting for marriage. At one time a report sent to the LMS read:

Why are you training boys only and not girls? We would like that girls should be trained as well as boys. We tell you this, because there are many teachers there who would marry trained girls, but they are disappointed because there are but few learned girls. We shall be very glad to hear you answer us and know the reason why you cannot do this. In this land we see very many trained girls and wonder why the girls in our country are not thus trained. ${ }^{6}$

The missional patriarchal ideology of providing male ministers with girls for marriage formed through the ecclesial circles was not different from the traditional system of child marriage that is still prevalent in the country today. Therefore, it can also be argued that the problems of child marriage are firstly both a religious and a cultural issue and secondly, it is as old as humanity itself. In the case of Mable Shaw girls' boarding school, Morrow reports that sometimes Shaw wrote to other missionaries to seek suitable husbands, normally ministers or evangelists, for GBS girls (1986:622). The call for educated girls through mission schools was a call for girls formed through the patriarchal standard of the church. The work of Oduyoye (1995) on how patriarchy has perpetuated the oppression of women can be justified by this kind of approach to mission and education. The demand for educated girls later created a standard in which the male elite measured how marriageable a church woman should be. Hence these girls were seen as 'educated for marriage' girls. Instead of empowering them to be independent to make decisions as to who or whether or not to marry, the school made marriage part of the requirement for the girls' educational standard. In 1929, Shaw wrote this statement "No girl leaves the school unmarried," as part of the school regulation; the statement was almost literally true since most of the girls married before they left the school. Besides the few girls left the school without marriage at the end of their school life, the majority were married in the last year of leaving school. Even those who did not get married during their school period were later married. Morrow reports that in assuming that all girls would marry before leaving school, the GBS did not differ from the pupils' own society, except that the school girls married later than was the norm for the time and place (Morrow 1986:622).

\section{Confinement and Seclusion of Students in Mission Schools}

The period of staying in the school for these girls was different from other boarding schools. In the MSGBS girls stayed in the school for ten months a year from age 5-18 years with very limited time of holidays in the year. The idea of keeping girls in confined boarding houses with convent like structures over a long period was one mode of

6 For further information see, LMS Chronicle, 23, n.s. 1915:93-95 quoted by Morrow "No Girl Leaves School Unmarried" 603. 
missionary training that was used as a way of setting apart the converts. As a way of protecting the colonists of heaven from a heathen society, missionaries introduced confinements that allowed the converts very limited time of being with their families. In one of her models of education for girls Shaw also aimed at colonising the African girls whom she considered backward and primitive (needing regeneration). Therefore, the seclusion from the rest of the society was also to deal with the mental capacity of these girls. The formation was intense and strenuous for girls but Shaw saw it as the only way of forming these African natives and preventing them from practising some of their African practices that were deemed to be evil by the missionaries.

\section{The Role of Missionaries in the Process of African Colonisation and Girls' Education}

In concluding this article, I draw three important points from the study in relation to the role of missionaries in the process of girls' education.

- First was the attitude of missionaries towards the indigenous communities which was ambivalent. Like any other missionary Shaw struggled to seesaw $;$ between positive and negative aspects of the indigenous people that could be attributed to the development of the girls in her school. We may argue that the girls that came from this school married at a later stage than those in the communities, and that they were also the elite of the society since some of them became teachers, and the majority married men who had good white-collar jobs working in the Zambian mines (Morrow 1986). In a context where marriage was the norm for every woman, the GBS failed to provide redemptive tools that would challenge that kind of culture. The school could have been a place where girls could find redemption from the oppressive nature of early marriage prevalent in their communities and pursue their western education that would provide them with career paths beyond marriage. A critical classical analysis of the missionary approach to Africans will show that they saw society as fundamentally divided by unequal power relations. Hence the intersection between gender, race, class and culture played a very important role in understanding the formation of a girl's education. A pedagogy approach that tries to underpin and bring to scrutiny some of the obscure arguments that were put across by Shaw in her education ideologies will show that her education model required further critique. Questions arise, such as, To what extent did religion influence decisions in the mission field? How did gender, race and class play themselves out among the missionary women such as Shaw in their interaction with the indigenous colonised women? In talking about colonialism and missionary influence to colonised societies, it's important to recognise the influence of these factors.

- Second is a need for a feminist hermeneutics that questions the concept of what Shaw saw as transformation. Instead of organising the formation of a girl around her community, Shaw took it upon herself to provide formation for the girl using her own Victorian missionary model as seen through a western lens. In this way she justified her education, showing that it brought enlightenment and religious thoughts to the "heathen girl-child living in the dark world.' This then calls for a need to question the concept of faith and its effect to colonialism. On the other hand, although Shaw tried to apply the theory of enculturation in the teaching of girls by letting learners be taught using their own African cultural frameworks in the initiation ceremony, she still failed to provide the kind of education that would be indigenous and redemptive to the girls in her school. This was evident in the teachings related to initiation ceremonies. Enculturation had its own challenges in that Shaw failed to bring both cultures into scrutiny. 
Enculturation without any feminist cultural hermeneutics as proposed by African women theologians simply reinforce the patriarchal oppression that is found in both religion and culture. The work by Kanyoro (2002) has shown that culture hermeneutics requires skills for crucial contextualisation of methods as well as the content of analysis. Failure to do that can lead to failure to communicate culture effectively. Siwila (2010) quotes Allen who observes that the LMS did not seek to offer the indigenous student a liberal education but rather the main interest was in basic literacy skills which only prepared the student with limited skills for development.

Third, despite the fact that some of Shaw's policies worked against the African ethos, the school gained firm ground especially among the girls who went through this education model. The girls from the GBS were praised by the communities as 'bakwashaw' ('those of Shaw'); the girls even saw themselves as elitists above the girls of Mbereshi Girls' Day School and other schools around the community, envied and emulated by them, and further still above ordinary village girls (1996:610). Siwila, (2010) quotes Parpart who confirms this statement saying that most of the wives of the better educated men in the Copperbelt province were often products of the Mabel Shaw boarding school.

\section{Conclusion}

This article has explored the work of Mable Shaw in introducing education of girls in Zambia by forming an all-girls boarding school. The article has displayed a number of ambivalences in the way in which the school was run. The conclusion in this article is that Shaw's feminist ideologies were ambivalent in that in as much as she seemed to be promoting the liberation of women, she failed to do so for the girls in her school. Instead, she perpetuated the patriarchal ideologies that promote marriage for women. Her feminist ambivalence also reflects how the coloniser - colonised relationship affected gender, race and class relationships in the mission field, especially among the women missionaries and the colonised women. The article has also proved that although imperialism was gendered during the colonial era, due to race privileges, white women also attained power over colonised men and women, as was the case with Shaw. Finally, the education model proposed by Shaw reflected both negative and positive aspects which helps us to understand that the missionary model of education did not only affect the African culture positively but that it also carried negative aspects that need to be explored further in our research scholarship.

\section{BIBLIOGRAPHY}

Berger, I 1999. "Women in East and Southern Africa" in Berger I and White F. Women in Sub-Saharan Africa: Restoring Women to History, Bloomington: Indiana University Press, pp. 5- 60.

Gaitskell, D 1979. "Christian Compounds for African Women in Johannesburg, 1907-1970.” Journal of Southern African Studies 6, no. 1:44-69.

Gaitskell, D 1983. "Housewives, Maids, or Mothers: Some Contradictions of Domesticity for Christian Women in Johannesburg, 1903-1939." Journal of African History 24, no. 2:241-56.

Hughes, R 2013. “The Legacy of Mabel Shaw.” International Bulletin of Missionary Research. Vol. 37, 2:105-108. 
Kanyoyo MR 2002. Introducing Feminist Cultural Hermeneutics: An African Perspective. Sheffield: Sheffield Academic Press

London Mission. Society 1915. Chronicle. 23:93-95

Marrow, S 1986. "The Missionary in the Black Girl” in Shaw. Vol. 6:5-12.

Morrow, S 1986. "NNo Girl Leaves School Unmarried': Mabel Shaw and the Education of Girls at Mbereshi, Northern Rhodesia 1915-1940”. The International Journal of African Historical Studies, Vol. 19 No 4:601-635, Boston University African Studies Centre.

Oduyoye, MA 2001. Introducing African Women's Theology. Sheffield: Sheffield Academic Press.

Oduyoye, Mercy, A 1995. Daughters of Anowa: African Women and Patriarchy. Mary Knoll: Orbis Books.

Parpart. J 1994. “'Where is Your Mother?': Gender, Urban Marriage and Colonial Discourses on the Zambian Copperbelt, 1924-1945." International Journal of Historical Studies, Vol. 27, No 2:241-271.

Phriri IA 2003. "African Women of Faith Speak out in an HIV and AIDS Era" in Phiri, IA Haddad, B, Madipoane M (eds.). African Women, HIV/AIDS and Faith Communities. Pietermaritzburg: Cluster Publication pp 3-22.

Ruether, RR 1993. Sexism and God-Talk:Toward a Feminist Theology. Boston: Beacon Press.

Shaw, M 1938. NAZ/NR 2/240, LMS, Mbereshi Girls' School and Jeanes 1938-54, Shaw to Tyndale-Biscoe, 8 April, Mbereshi.

Siwila, LC 2011. "Problematizing a 'Norm': A Religio-cultural Gender Analysis of Child Marriage in the Context of HIV and AIDS". Journal of Gender and Religion in Africa, vol. 17.1 July. 